\title{
ENTEROVIRUS ISOLADOS DE PACIENTES COM AFECÇÕES DO SISTEMA NERVOSO
}

\author{
R. P. de Souza Carvalho*
}

A. Spina-França *

Os vírus da poliomielite, os virus Coxsackie $\mathrm{A}$ e $\mathrm{B}$ e os virus ECHO são grupados como enterovírus humanos e costumam determinar infecções transitórias, na maioria das vêzes inaparentes, do aparelho digestivo e da rinofaringe. Em algumas ocasiōes ocorrem manifestaçōes clínicas da infecção, a qual pode comprometer também outros órgãos e aparelhos. Entre os quadros neurológicos determinados por enterovírus destacam-se, pela freqüência, o de poliomielite anterior aguda e o de leptomeningite aguda.

O mesmo vírus pode determinar quadros clínicos diversos, da mesma forma que o mesmo quadro clínico pode resultar da infecção do organismo por vários tipos de vírus. Esse fato é um dos óbices à utilização do quadro clínico para a classificação dos enterovírus; como êstes contêm substâncias antigênicas que são capazes de induzir a produção de anticorpos, dá-se preferência a classificações baseadas em dados imunológicos. Assim, aceita-se atualmente a existência de três tipos imunológicos de vírus da poliomielite; 23, de vírus Coxsackie $\mathrm{A} ; 6$, de virus Coxsackie $\mathrm{B}$ e 32 , de vírus ECHO.

Em nosso meio, a partir da década passada, têm sido desenvolvidos estudos na tentativa de isolar enterovírus de pacientes com quadros clínicos provàvelmente determinados por vírus. Um de nós, refere as contribuições publicadas até a época em que apresentou análise da sua casuística sôbre o assunto ${ }^{1}$. Esta casuística abrange experiência reunida no decorrer de período de cêrca de 9 anos (1956-1964) e é representada pelo isolamento de 128 enterovírus - por semeadura em cultivo de células ou inoculações em camundongos recém-nascidos - a partir de tentativas feitas com fezes e/ou líquido cefalorraqueano (LCR), secreção da rinofaringe, porções da medula, de encéfalo e de miocárdio de 407 pacientes. Dêsses vírus, 108 eram da poliomielite, 7 eram Coxsackie A, 6 eram Coxsackie B, 6 eram ECHO e um, enterovirus não tipado. Além dêsses enterovirus, foram isolados também 19 adenovirus. Do total dos casos, 141 apresentavam quadro clínico de poliomielite anterior aguda, tendo sido isolados das fezes dêsses pacientes 79

Trabalho dos Departamentos de Microbiologia e Imunologia (Prof. C. da Silva Lacaz) e de Clínica Neurológica (Prof. A. Tolosa) da Fac. Med. da Univ. São Paulo:

* Professor assistente. 
enterovírus: 72 vírus da poliomielite (38 do tipo $1 ; 19$ do tipo $2 ; 15$ do tipo 3), 4 vírus Coxsackie (dois do tipo A-13; um do tipo B-1 e um do tipo B-5) e três vírus ECHO (um do tipo 6; um do tipo 7 e um do tipo 11). Das fezes ou de medula espinhal de 54 crianças que faleceram de poliomielite anterior aguda foram isolados 19 vírus da poliomielite (10 do tipo 1; 8 do tipo 2 e um do tipo 3), um vírus Coxsackie B-5, além de 7 adenovírus. Das fezes de 59 pacientes com quadros neurológicos que poderiam ser determinados por vírus, em 9 foram isolados 11 enterovírus: 7 da poliomielite (dcis do tipo 1; um do tipo 2 e 4 do tipo 3 ), dois Coxsackie A-1, um Coxsackie A-13 e um, não tipado. Nenhum vírus foi isolado a partir de amostra de LCR.

Além da poliomielite anterior aguda, outras afecções do sistema nervoso clàssicamente atribuiveis a virus puderam, portanto, ter seu diagnóstico etiológico elucidado. Considerando o interêsse da pesquisa de virus em tais casos, dos 59 casos referidos destacamos para êste estudo, 16 que foram encaminhados através da Clínica Neurológica da Faculdade de Medicina da Universidade de São Paulo, para ilustrar os resultados que podem ser obtidos mediante a utilização do exame.

\section{MATERIAL E METODOS}

Foram estudados 16 pacientes com afecções do sistema nervoso associadas, ou nāo, a reaçāo leptomeningítica, nos quais a possibilidade de tratar-se de processo inflamatório desencadeado por virus não pôde ser excluída clínica ou laboratorialmente (tabela 1).

Dos 16 pacientes, 5 apresentavam sintomatologia atribuivel a encefalite, dois a meningencefalite, um a encefaloneurite, um a mielite, 4 a meningomielite, dois a radiculomielite e um a polirradiculoneurite. Em três pacientes o estudo foi feito durante a primeira semana de doença; em 10, de uma semana a um mês após o início da doença e em três, após o primeiro mês de doença. A tentativa de isolamento de vírus a partir das fezes foi feita em 11 pacientes; em 8 dêstes a tentativa foi feita também a partir do LCR; em 5 casos o isolamento de virus só foi tentado a partir de amostra de LCR. Em 5 pacientes foram encaminhadas, para verificação da presença de anticorpos neutralizantes, duas amostras de sôro colhidas: a primeira por ocasiāo da data em que foi encaminhado material para isolamento de vírus e a segunda, de 7 a 15 dias depois. Em 8 casos foi possivel obter apenas uma amostra de sôro para êsse fím e em três, nenhuma amostra.

A pesquisa de virus foi feita mediante semeadura em cultivos de tecido e inoculação em camundongos recém-nascidos de LCR e/ou suspensão de fezes. As técnicas empregadas para êsse fim foram apresentadas em detalhe anteriormente, bem como aquelas referentes à identifícaçāo dos vírus isolados e à pesquisa de anticorpos neutralizantes em amostras de soros dos pacientes a partir dos quais o vírus fôra isolado ${ }^{1}$.

\section{RESULTADOS}

Não se conseguiu isolar virus a partir das amostras de LCR. Dos 11 casos em que a tentativa foi feita a partir das fezes, foram isolados 4 enterovirus de três pacientes. Dêstes, a pesquisa de anticorpos neutralizantes foi feita em apenas um caso e assim mesmo em uma amostra de sôro. 


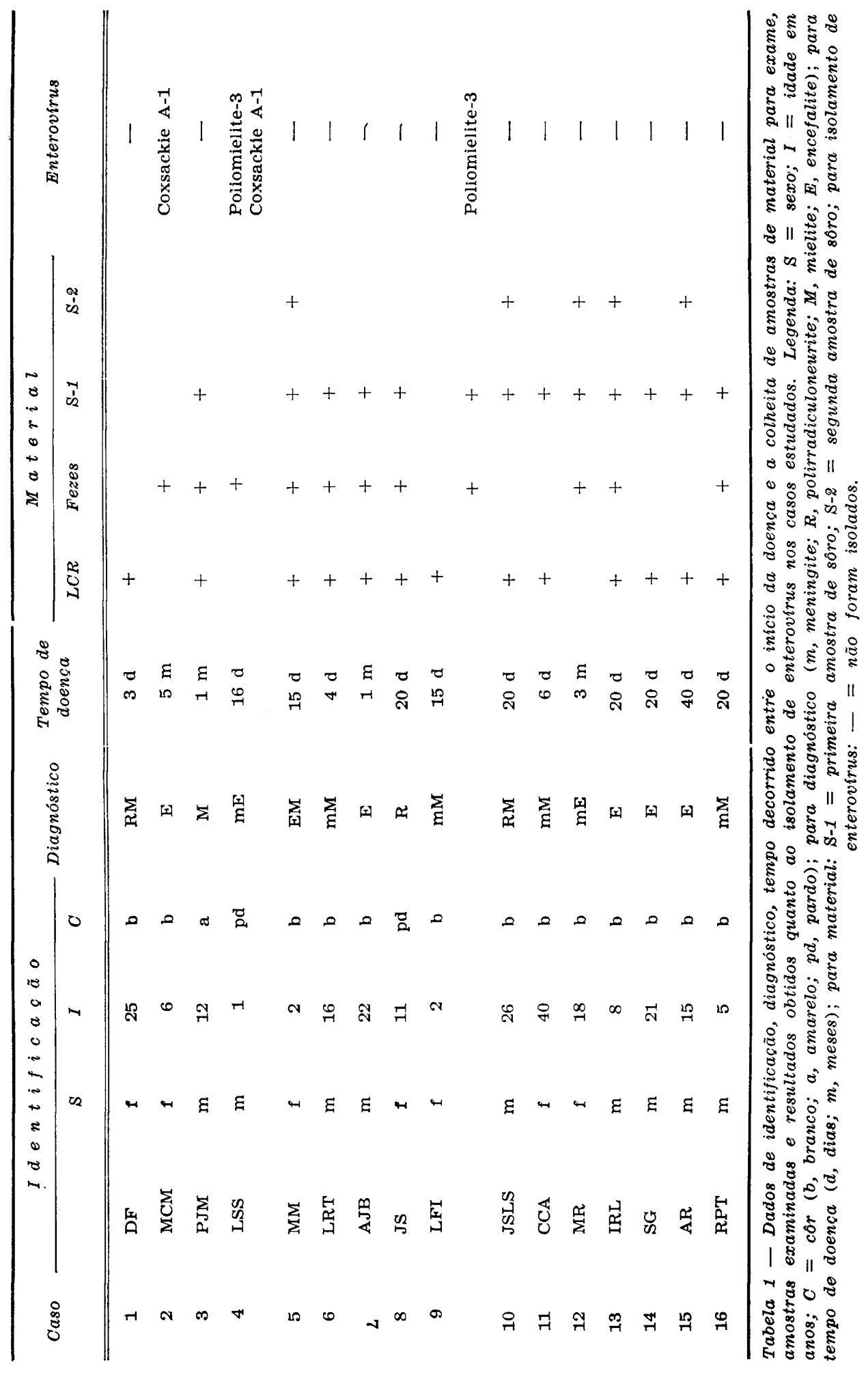


A paciente MCM (caso 2), de 6 anos de idade, apresentava sintomatologia que se iniciara por episódio gripal que perdurou por uma semana e que era acompanhado de cólicas abdominais e hipertermia. A sintomatologia neurológica se iniciou nessa ocasiāo também, por crises convulsivas generalizadas. Posteriormente tais crises se tornaram freqüentes e a paciente passou a apresentar alheiamento progressivo ao meio ambiente, bem como diffculdade à deglutição. Internada 4 meses depois, encontrava-se afebril, caracterizando-se o quadro neurológico por rebaixamento global das funções mentais e sindrome pirâmido-extrapiramidal. O exame do LCR foi normal e o eletrencefalograma evidenciou disritmia difusa. Houve piora progressiva até que a paciente faleceu. Não foi feita necropsia. A pesquisa de vírus foi feita a partir das fezes, 5 meses depois do início da doença, tendo sido isolado em camundongo recém-nascido vírus Coxsackie $A-1$. Não foi feita pesquisa de anticorpos neutralizantes no sôro dessa paciente.

A paciente LSS (caso 4), de um ano de idade, apresentara 10 dias antes da internação quadro infeccioso agudo, seguido, 4 dias depois, de aparecimento de sintomatologia de sofrimento encefálico. Nessa fase um exame de LCR revelou pleocitose discreta predominantemente linfomononuclear. Por ocasião da internação apresentava sindrome pirâmido-extrapiramidal, exame do LCR normal e moderada desorganização da atividade elétrica cerebral ao exame eletrencefalográfico. Alta cêrca de um mês depois em condições inalteradas. A pesquisa de vírus foi feita nas fezes, 16 dias após o inicio da doença, sendo isolado em camundongo recémnascido virus Coxsackie $A-1$ e, em cultura de células Hela, vírus poliomielite tipo 3. Também neste caso não fol feita pesquisa de anticorpos neutralizantes no sôro.

A paciente LFI (caso 9), de dois anos de idade, apresentava déficit motor no membro superior esquerdo, que surgira na vigência de processo infeccioso agudo, cêrca de 10 dias antes da internaçảo. O quadro neurológico se caracterizava por discreta rigidez de nuca, paresla e arreflexia profunda no membro comprometido e sinal de Babinski também à esquerda; o quadro liquórico caracterizava-se por discreta pleocitose linfomononuclear isolada. Houve regressão progressiva da sintomatologia e 18 dias depois, por ocasião da alta, persistia discreto déficit no membro superior esquerdo apenas. A partir das fezes foi isolado, 15 dias depois do inicio da doença e mediante cultivo de células amnióticas humanas, vírus poliomielite tipo 3. Na amostra de sôro obtida de sangue colhido nessa mesma ocasião foram encontrados os seguintes títulos de anticorpos neutralizantes: antivirus poliomielite tipo 1 , inferior a 1/4; antivirus poliomielite tipo 2 , inferior a $1 / 4$; antivirus poliomielite tipo 3 , superior a $1 / 256$.

\section{COMENTARIOS}

Dos 16 pacientes estudados, 6 apresentavam idade não superior a 10 anos; 5, idade entre 10 e 20 anos; 4, entre 21 e 30 anos e um, 40 anos. Apenas entre os pacientes com menos de 10 anos de idade é que foram isolados enterovirus; apresentavam êles um, dois e 6 anos de idade, respectivamente.

Os enterovírus foram isolados de fezes de paciente com quadro clínico sugestivo de encefalite (um caso), meningencefalite (um caso) e meningomielite (um caso). No primeiro foi isolado virus Coxsackie A-1, no segundo, vírus Coxsackie A-1 e vírus da poliomielite tipo 3 e, no terceiro, vírus da poliomielite tipo 3 . Não se pode excluir que o vírus da poliomielite isolado no caso 2 estivesse na dependência da vacina Sabin administrada ao paciente anteriormente; embora não tenha sido possivel esclarecer com precisão a época em que tal vacina fôra administrada, o fato de o paciente ter um ano de idade sugere que não decorrera ainda intervalo de tempo grande entre a administração da vacina e a feitura do exame. 
Assim sendo, no material apresentado, o isolamento do vírus Coxsackie foi conseguido em dois pacientes com sinais clinicos sugestivos de encefalite, que se faziam acompanhar de comprometimento leptomeníngeo em um dêles. O vírus de poliomielite do caso 9 foi isolado de paciente com meningomielite em que predominavam sinais de comprometimento de côrno anterior da medula.

Em sua maioria, os pacientes foram encaminhados à Clínica Neurológica algum tempo após o inicio da doença, geralmente depois da fase aguda da dcença. Esse fato pode ter determinado diminuição da probabilidade de isolamento de vírus. Por outro lado, quando se isolam vírus em periodos tardios da evolução - como ocorreu no caso de encefalite em que o vírus Coxsackie foi isolado das fezes cêrca de 5 meses depois do inicio da doença - não se pode excluir que não seja êsse o vírus responsável pela manifestação clínica. $\mathrm{Na}$ interpretação dos dados dêsse caso, outro fator que dificulta atribuir ao vírus isolado a etiologia do processo é o fato de não ter sido feita determinação da presença dos respectivos anticorpos neutralizantes no sôro da paciente e nem exame necroscópico.

Da mesma forma, a constatação da presença de vírus Coxsackie nas fezes da paciente com meningencefalite, embora sugestiva, não permite conclusōes definitivas porque, neste caso, não foi feita também a devida pesquisa de anticorpos neutralizantes no sôro da paciente. Na paciente com meningomielite, em que o vírus da poliomielite tipo 3, foi isolado das fezes cêrca de duas semanas depois do início da doença, demonstrou-se no sôro elevado título de anticorpos neutralizantes dêsse vírus apenas. Essse fato permite relacionar, com maior segurança, o processo apresentado pela paciente ao vírus isolado.

Em nosso meio, Góes e col. ${ }^{2,3}$, referem ter isolado virus Coxsackie A e $B$ de pacientes com afecções neurológicas (meningencefalite, meningite asséptica, neuromielite, encefalite, estados febris acompanhados de fenômenos paraliticos e outros), no Rio de Janeiro, em 14,5\% dos casos examinados. Algumas vêzes, o papel etiológico do virus encontrado foi significativo em virtude do isolamento do vírus no LCR ou do aumento dos anticorpos específicos. Silva e col. ${ }^{5}$ estudaram 12 casos de meningite asséptica e encefalite, no Rio Grande do Sul, tendo isolado em um caso vírus poliomielite tipo 1.

A adoção de pesquisas virológicas sistematizadas em pacientes com afecções do sistema nervoso e/ou de seus envoltórios passíveis de ser determinadas por vírus representa recurso que permite esclarecer de modo adequado o diagnóstico em muitas ocasiões. A freqüência em que isto ocorre depende dos recursos com que se pode contar, os quais devem permitir o estudo não apenas de enterovirus, como de outros grupos de vírus. Como exemplo, é de lembrar que a melhoria dos recursos nesse sentido tornou possivel que no laboratório de virologia do Walter Reed Hospital, no periodo de 1953 a 1958, dos 713 casos com prováveis neuroviroses estudados se chegasse ao diagnóstico etiológico em $73 \%$ dêles ${ }^{4}$. Essa cifra representa cêrca de três vêzes a percentagem registrada na década anterior nesse mesmo laboratório, quando se contava com recursos mais limitados. Por outro lado, 
nessa mesma estatística, é elevada a freqüência em que outros vírus, que não os enterovírus, foram isolados em casos de meningite e de encefalite, fato que vem patentear a necessidade das pesquisas nesse sentido serem feitas do modo mais amplo possivel.

\section{RESUMO E CONCLUSOES}

Em 16 pacientes com afecções do sistema nervoso em que a etiologia a virus não pôde ser excluída clínica ou laboratorialmente, foi feita a pesquisa de enterovírus nas fezes ( 3 casos), no LCR ( 5 casos) ou nas fezes e no LCR (8 casos). Não foram isolados enterovírus a partir das amostras de LCR. A partir das fezes foram isolados vírus em um caso de encefalite (virus Coxsackie A-1), em um caso de meningencefalite (vírus Coxsackie A-1 e poliomielite tipo 3) e em um caso de meningomielite em que predominavam sinais de comprometimento do côrno anterior da medula (vírus poliomielite tipo 3). Como o paciente com meningencefalite apresentava um ano de idade e anteriormente ao início da doença recebera vacina Sabin, não se pôde excluir que nesse caso o poliovírus isolado esteja relacionado com a vacinação. Nos dois pacientes em que foi isolado vírus Coxsackie não foi possivel fazer estudo da presença de anticorpos neutralizantes no sôro respectivo. Este fato leva a que não seja possivel concluir quanto à correlação existente entre a presença do vírus nas fezes e a etiologia do quadro neurológico dos pacientes. Apenas no paciente com meningomielite em cujas fezes foi isolado virus poliomielite tipo $3 \mathrm{e} \mathrm{em} \mathrm{cujo} \mathrm{sangue} \mathrm{o} \mathrm{tí-}$ tulo de anticorpos neutralizantes dêsse virus era elevado foi possível relacionar, com maior segurança, o vírus isolado à etiologia do processo neurológico.

Êsses dados representam orientação quanto a estudos futuros, permitindo sugerir que o estudo virológico deva ser feito precocemente e incluir o estudo concomitante de anticorpos neutralizantes no sôro. Por outro lado, o isolamento dos enterovírus referidos sugere que os estudos devam ser ampliados em nosso meio nesse sentido, incluindo também a pesquisa de outros tipos de vírus.

\section{SUMMARY}

Isolation of enterovirus from patients with diseases of the nervous system

From 16 patients, presenting diseases of the nervous system, porbably of viral etiology, cerebrospinal fluid and/or stool samples have been collected for virus isolation in cell culture and in sucking mice. The technical methods adopted have been previously related by one of us. Enterovirus have been isolated from stools of 3 patients: virus Coxsackie $A-1$, from a patient with encephalitis, virus Coxsackie A-1 and poliovirus type 3 , from a patient with meningo-encephalitis; and poliovirus type 3 , from a patient with meningo-myelitis. High titer of neutralizing antibodies against poliovirus type 3 was found in the last case, the only positive case in which serum was 
collected. There is a possibility that the poliovirus isolated from the patient with meningo-encephalitis was originated from the previous Sabin vaccination. The etiological significance of the isolations of Coxsackie A-1 virus in the first two cases was considered insufficient, as it was not possible to evaluate the presence of homotipic neutralizing antibodies.

\section{REFERENCIAS}

1. Carvalho, R. P. S. - Contribuição para o estudo dos enterovírus. Tese. Faculdade de Medicina, Universidade de São Paulo, São Paulo, 1965. 2. GóES, P.; VASCONCELlOS, J. V.; SCHWARTZ, N. M.; GOLDAHEIL, R.; TRAVASSOS, J. Ocorrência de vírus Coxsackie no Rio de Janeíro. VI. Isolamento do vírus em síndromes neurológicos. An. Microbiol. 3:125-137, 1954-55. 3. GóES, P.; TRAVASSOS, J.; VASCONCEllos, J. V. - Ocorrência de virus Coxsackie no Rio de Janeiro. $\mathrm{X}$. Virus e quadros clínicos observados. An. Microbiol. 6:13-35, 1958. 4. MEYER Jr., H. M.; JOHNSON, R. T.; CRAWFORD, I. P.; DASCOMB, H. E.; ROGERS, N. G. Central nervous system syndroms of viral etiology. A study of 713 cases. Amer. J. Med. 29:334-347, 1960. 5. SIlvA, N. N.; FERLIN, D.; SANTOS, W. R.; HAAS, I. - Isolamento e tipagem de enterovirus de 72 casos de poliomielite paralitica e 12 casos de meningite asséptica. O Hospital 68:7-11, 1965.

Clinica Neurológica - Faculdade de Medicina da Universidade de Sĩo Paulo - Caixa Postal 3461 - São Paulo, SP - Brasil. 